\title{
Assessment of groundwater quality in a semiarid region of Northwestern Algeria using water quality index (WQI)
}

\author{
Abdelkader Hamlat $^{1}$ (D) . Azeddine Guidoum ${ }^{1}$
}

Received: 8 August 2017 / Accepted: 31 October 2018 / Published online: 11 November 2018

(c) The Author(s) 2018

\begin{abstract}
The present paper aims at determining the status and trends of groundwater quality of 12 aquifers situated in Northwestern Algeria, especially under conditions of last drought that has affected the region using water quality index (WQI) over a period of 4 years. Multivariate statistical methods have been used jointly with conventional graphical methods, to classify the samples according to plausible levels of groundwater evolution. The computed WQI values range from 67 to 588 and therefore can be categorized into four categories: "good water" to "water unsuitable for drinking." Overall, $36 \%$ of groundwater sites sampled in the study area had good water quality, while $53 \%$ were poor. Unfortunately, $6 \%$ of the samples indicate "very poor water quality" and 5\% represent water "unsuitable for drinking purposes." Results show that the majority of groundwater of Tafna basin fell under good water quality. Groundwater of poor and medium quality characterizes the majority of the studied aquifers of Macta basin. The result showed that the water quality at monitoring station "Ain Skhouna" fell under good water quality (Chott Chergui aquifer). Results also show that groundwater of Coastal Oranais basin showed poor water quality, very poor at some monitoring stations of Mléta Plain aquifer. It has been demonstrated that the water of some aquifers has degraded under water scarcity conditions and will continue to degrade given the ongoing and projected development in the study area. The analysis reveals that the water of some aquifers needs treatment before it is used for human consumption. The influence of salt water on the some freshwater aquifers in the study area needs special attention in terms of monitoring and for sustainable management.
\end{abstract}

Keywords Coastal Oranais basin · Drought · Groundwater quality · Northwestern Algeria · Water quality index · Tafna

\section{Introduction}

Algeria's water is not always in the right place at the right time to meet the current and future needs. Algeria suffers a severe shortage of freshwater since most of its territory is classified as arid and semiarid zones. The northern coastal regions of the country are more densely populated; nearly $90 \%$ of the population lives in urban areas which represent $10 \%$ of the country's area (Sadi 2004). Algeria lies below the desirable resource threshold of $1000 \mathrm{~m}^{3} /$ year per inhabitant (Iglesias et al. 2006a); it is ranked sixth among countries suffering most severely from water shortage, and it will jump

Abdelkader Hamlat

a.hamlat@lagh-univ.dz

1 Research Laboratory of Water Resources, Soil and Environment, Department of Civil Engineering, Amar Telidji University, Boulevard of the Martyrs, P.O. Box 37.G, 03000 Laghouat, Algeria to fourth place by the year 2025 if no suitable alternative solution to the water shortage problem is adopted (Mitiche et al. 2010).

In the last two decades, Northwestern Algeria in particular has experienced severe and persistent droughts with annual rainfall some 30 percent below average (Meddi and Hubert 2003; Touchan et al. 2008; Masih et al. 2014); this has affected remarkably the availability of water and overall socioeconomic activities. Silting of dams is another factor that strongly affects water resources in the region; and there are currently ten large dams some of which are currently facing a high rate of siltation; Fergoug and Bouhanifia dams are silted over $90 \%$ and $50 \%$, respectively (MRE 2010). Groundwater resources at region scale are widely used to meet agricultural, domestic and industrial water requirements. The potential for available exploitable groundwater of Northwestern Algeria basins has been estimated by ANRH (National Water Resources Agency) to 428.52 MCM though withdrawals are estimated to be 391

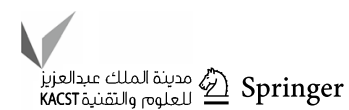


MCM which means that some of the aquifers are overexploited (e.g., Ghriss Plain aquifer) mainly due to increasing water demand (Bekkoussa et al. 2008).

The problem of water quality is another factor that affects the availability of water resources in Northwestern Algeria. Studies show that there is a significant amount of wastewater that continues to spread into the environment without treatment. Some $73 \mathrm{MCM} /$ year of effluents is discharged untreated into the receptor environment (MRE 2010), and this contributes to worrying levels of pollution both for surface water and for alluvial groundwater.

Various assessment tools have been utilized to quantify the water chemistry and status of water quality. Water quality index (WQI) is one of the most effective tools to obtain a comprehensive picture of the water quality; it is a mathematical instrument used to transform large quantities of water characterization data into a single number that expresses overall water quality at a certain location and time (Tyagi et al. 2013; Singh et al. 2013a, b; Tiwari et al. 2015).

The use of a WQI was first formulated by Horton (1965) and then developed by Brown et al. (1970). Various indices have been formulated and developed by many researchers as tools for simplifying the representation of water quality data in particular groundwater quality. (Tiwari and Mishra 1985; Backman et al. 1998; Stambuk-Glijanovik 1999; Soltan 1999; Kasim et al. 2007; Queralt et al. 2008; Taheriyoun et al. 2010; Pei-Yue et al. 2010; Jinturkar et al. 2010; Ketata et al. 2011; Tiwari et al. 2014; 2017a, b).

Current groundwater assessment and monitoring at a national scale are temporally and spatially fragmented, and there is inadequate use of data and information generated by monitoring activities (ABHOCC 2009a, b; MRE 2009; ABHOCC 2012). Groundwater quality evaluation has been carried out by ANRH using traditional approaches that are based on a comparison of experimentally determined parameter values with the local norms (ABHOCC 2006a, $\mathrm{b}, \mathrm{c})$; the process is lengthy, complex and labor intensive. As a result, water quality managers are unable to provide a more accurate picture of overall water quality.

The main objective of this study is to understand the groundwater quality status of 12 aquifers situated in Northwestern Algeria, especially under conditions of last drought that has affected the region; an attempt has been made for the first time to evaluate overall water quality using WQI, with the aim of identifying places with the best quality for drinking. Various physicochemical parameters have been used to asses suitability of groundwater for domestic purpose such as $\mathrm{pH}$, total dissolved solids (TDS), bicarbonate $\left(\mathrm{HCO}_{3}\right)$, electrical conductivity (EC), calcium $(\mathrm{Ca})$, magnesium $(\mathrm{Mg})$, sodium $(\mathrm{Na})$, potassium $(\mathrm{K})$, sulfate $\left(\mathrm{SO}_{4}\right)$, nitrate $\left(\mathrm{NO}_{3}\right)$, phosphate $\left(\mathrm{PO}_{4}\right)$ and chloride $(\mathrm{Cl})$.

\section{Materials and methods}

\section{Study area and sampling sites}

The study area is situated in the northwest of Algeria located between $0^{\circ} 59^{\prime} 40.03^{\prime \prime} \mathrm{E}$ and $-1^{\circ} 59^{\prime} 47.90^{\prime \prime} \mathrm{W}$ and from $36^{\circ} 25^{\prime} 13.28^{\prime \prime} \mathrm{N}$ to $34^{\circ} 0^{\prime} 26.18^{\prime \prime} \mathrm{N} \mathrm{E}$ (cf. Fig. 1). It includes the largest urban centers (Oran, Ain Témouchent, Tlemcen, Sidi Bel Abbes, Saida and Mascara), large industrial units and largest hydroagricultural potentials such as large irrigation systems of Habra-Sig, Maghnia, Tafna Valley and Ain Skhouna.

Sampling sites are located within Tafna, Coastal Oranais, Macta and Chott Chergui catchments (cf. Fig. 2). The Tafna basin is a transboundary catchment area; many socioeconomic activities of Oran, Tlemcen and Sidi Bel Abbes cities depend on water from this basin. The Macta is the second most important basin in the region because of its important water resources and soil potentialities. The Chott Chergui basin represents a transitional area between the semiarid highlands in the north to the arid in the south.

The study area is featured by a Mediterranean climate regime with a relatively cold and rainy winter and a hot and dry summer. The rain occurs mainly from November till March with occasional thunder storms in October and April. The annual rainfall reaches $400 \mathrm{~mm}$ (Meddi and Hubert 2003).

Two-thirds of the water resources are used for irrigation and one-third for potable and industrial use (UNEP and WRC 2008). The demand and competition for water are high in the studied area. The region's population was 5,805,658 in 2015 and was estimated to be $8,473,189$ in 2030 . Further, the projections indicate that the available water resources will not be able to fully meet the water demand by 2030 (Hamlat et al. 2013). It is therefore imperative that non-conventional water resources should be used; some desalination plants have been established to meet shortage and cover water needs in the study area (e.g., Plage El Hillal, 200,000 $\mathrm{m}^{3} /$ day; Souk Tlata, 200,000 $\mathrm{m}^{3} /$ day; Honaine, $200,000 \mathrm{~m}^{3} /$ day; and Macta, 500,000 $\mathrm{m}^{3} /$ day) (MRE 2009).

Northwestern Algeria geology is characterized by a great lithological and structural variability. It is dominated by quaternary formations, generally alluvial, different plains, while the mountainous massifs are characterized by a lithology which varies from region to region. The western area of the region is marked by a succession of horsts and graben that are ENE-WSW oriented from mounts of Tlemcen to mounts of Traras. This tectonics which compartmentalized limestone formations has had an effect of isolating karstic aquifers from each other (MRE 2009).

From a hydrogeological point of view, there are three main types of aquifers - alluvial aquifers along the coastal 


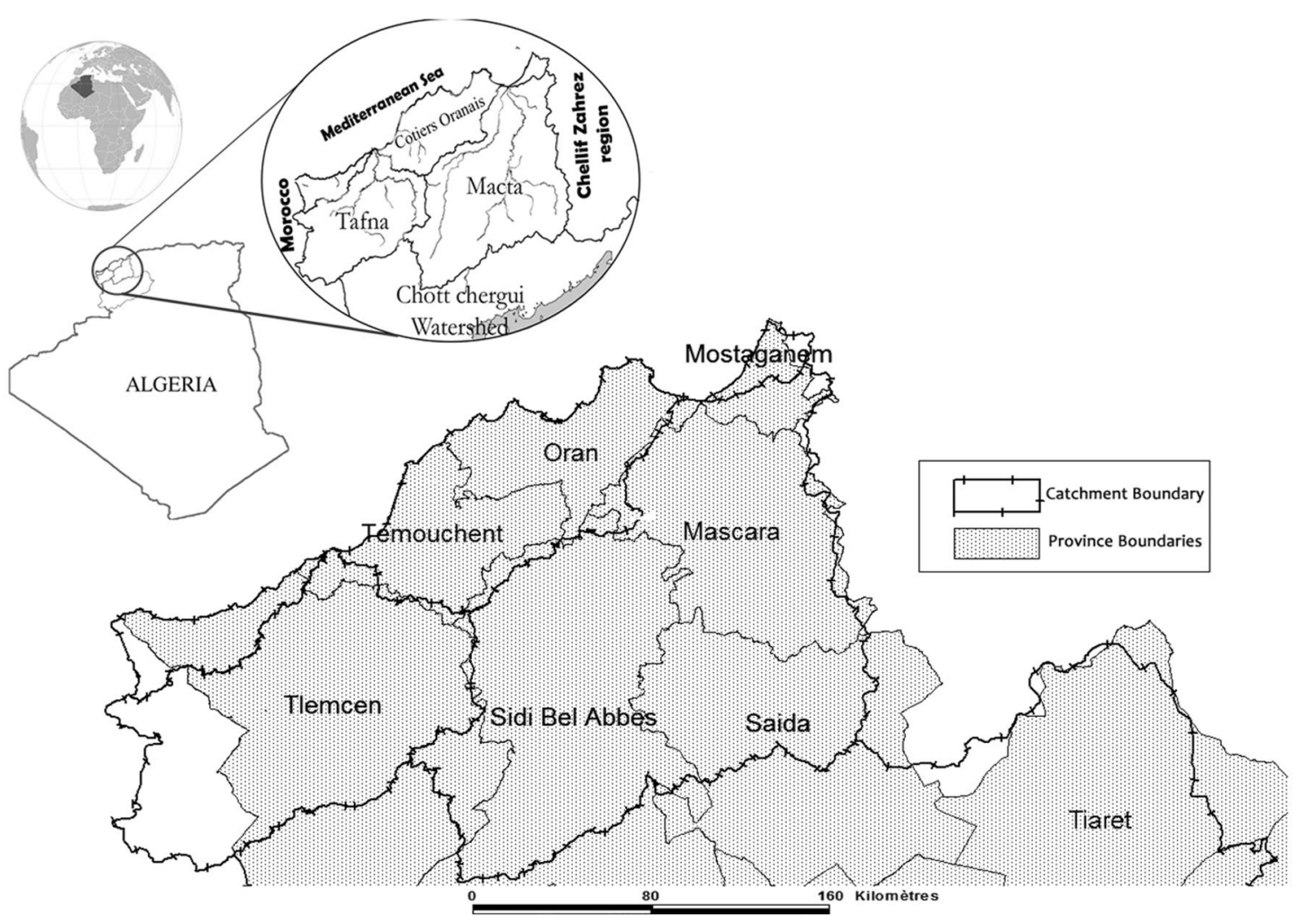

Fig. 1 Location of study area

plains which receive recharge from infiltration of rainfall; limestone and sandstone aquifers in mountains area; and alluvial aquifers along the major river valleys (FAO 2009).

Groundwater quality monitoring data were collected from January 2001 through December 2006 at 32 groundwater sites; the study period corresponds to all of the available data at each station that represents a trade-off between the temporal and spatial coverage afforded by the selected data set. This study period is also coincident with the period of last severe drought that has affected the study area; it needs to be noted that the current study of groundwater quality data was carried out to determine how groundwater quality has been affected under these water scarcity conditions. The database comprised the analyses for 235 groundwater samples, for a total of 4465 individual chemical measurements. The geographical latitude and longitude for all the sampling locations of the study area are presented in Table 1.

The laboratory analyses include major ions, trace elements and nutrients such as $\mathrm{pH}$, TDS, total hardness, bicarbonate, chloride, sulfate, nitrate, calcium, magnesium and sodium.

The analyses were carried out for internal precision by means of an ionic balance. Results of an error of ionic balance greater than 5\% were rejected (Kortatsi 2009). The expression that was evaluated is written as follows:
Error $(\%)=\frac{\sum \text { cations }-\sum \text { anions }}{\sum \text { cations }+\sum \text { anions }} \times 100 \%$

Approximately $96 \%$ of the measured water samples were within this range.

\section{Water quality index method}

The WQI provides a reliable picture of surface and groundwater quality for most domestic uses; it is easily understandable for decision makers about quality and possible uses of any water body (Ravikumar et al. 2013). The use of a WQI was first formulated by Horton (1965) and then developed by Brown et al. (1970). Various WQIs have been formulated all over the world that can be used to assess overall water quality in particular groundwater quality. Tiwari and Mishra (1985) presented an index for the assessment of groundwater quality mainly in some regions of India. Afterward, Backman et al. (1998) have developed a groundwater contamination index. Stambuk-Glijanovik (1999) developed a WQI for the estimation of water quality status in Dalmatia region, Croatia. Likewise, Soltan (1999) proposed a WQI to assess the water quality from artesian wells located near Dakhla oasis, Egypt. Kasim et al. (2007) have developed a 


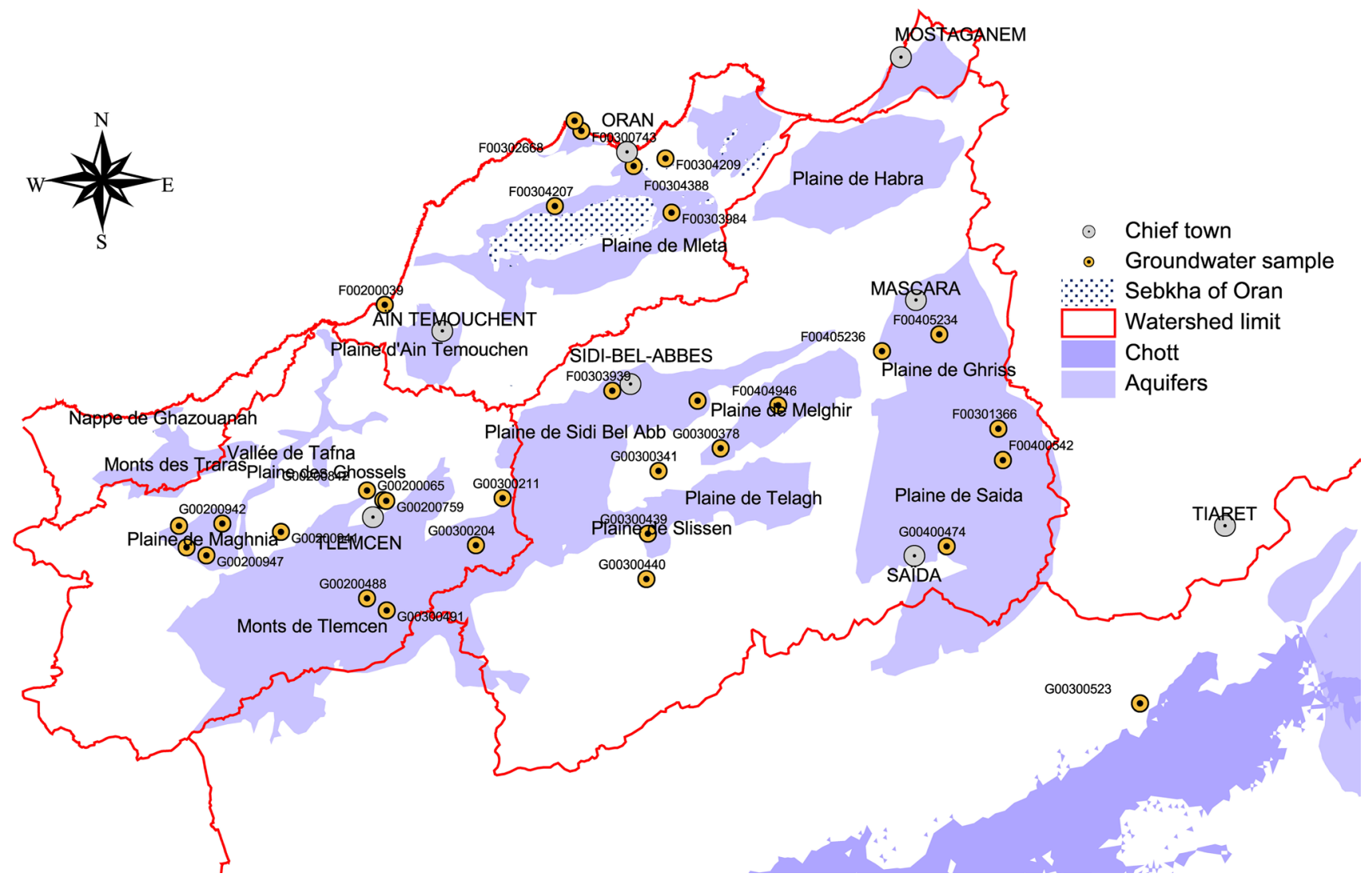

Fig. 2 Geographical location of the studied groundwater

WQI to study the impact of the landfill on the groundwater in Sabak area, Malaysia. Queralt et al. (2008) have presented an economic quality index for evaluating the state and the variations in groundwater quality in some aquifers in Catalonia, Spain. Taheriyoun et al. (2010) have developed an entropy-based fuzzy eutrophication index for reservoir water quality evaluation. Likewise, Pei-Yue et al. (2010) have used the concept of information entropy for the evaluation of groundwater quality in Pengyang County, China. Jinturkar et al. (2010) have developed WQI using fuzzy logic for the evaluation of groundwater quality at Chikhli, India. Several authors have used the WQI with geographical information systems (GIS) for assessing and mapping of groundwater quality (Ketata et al. 2011; Abbasi and Abbasi 2012; Tiwari et al. 2014; Tiwari et al. 2017a, b).

The WQI has been calculated to evaluate the suitability of groundwater quality of 12 aquifers situated in Northwestern Algeria for drinking purposes. The physical and chemical parameters of $\mathrm{pH}, \mathrm{TDS}, \mathrm{Ca}, \mathrm{Mg}, \mathrm{Na}, \mathrm{K}, \mathrm{HCO}_{3}$, $\mathrm{Cl}, \mathrm{SO}_{4}, \mathrm{NO}_{3}, \mathrm{EC}$ and $\mathrm{PO}_{4}$ were determined. To compute WQI, four steps are followed. In the first step, each of the 12 parameters has been assigned a weight $\left(w_{i}\right)$ according to its relative importance in the overall water quality for drinking purposes (cf. Table 2). The maximum weight of
5 was assigned to total dissolved solids and nitrate, considering that these often influence groundwater quality the most. Phosphate and magnesium were given the minimum weight of 1 as the two rarely play a significant role in groundwater quality. Potassium, calcium, chloride, conductivity, bicarbonate, sulfate and sodium were assigned weight ranging between 1 and 5 . In the second step, the relative weight $\left(W_{i}\right)$ is computed using a weighted arithmetic index method given below in the following steps (Sahu and Sikdar 2008; Vasanthavigar et al. 2010; Tiwari et al. 2014).

$W_{i}=w_{i} / \sum_{i=1}^{n} w_{\mathrm{i}}$

where $\mathrm{W} i$ is the relative weight, wi is the weight of each parameter and $\mathrm{n}$ is the number of parameters.

In the third step, a quality rating scale $\left(q_{i}\right)$ for each parameter was assigned using the equation:

$q_{i}=\left(C_{i} / S_{i}\right) * 100$

where $\mathrm{q} i$ is the quality rating, $\mathrm{C} i$ is the concentration of each chemical parameter in each water sample in milligrams per liter and $S_{i}$ is the drinking water standard for each chemical 
Table 1 Sampling location with their latitude and longitude

\begin{tabular}{|c|c|c|c|c|c|}
\hline Watershed & Aquifer & Station ID & Station name & LAT & LONG \\
\hline \multirow[t]{7}{*}{ Coastal Oranais } & \multirow[t]{2}{*}{ Coastal Oranais Plain } & F00300743 & Ain Turk & 35.74426 & -0.78194 \\
\hline & & F00302668 & EAC N7 & 35.76579 & -0.8017 \\
\hline & Bredeah Plain & F00304207 & Station of Bredeah & 35.57591 & -0.84636 \\
\hline & \multirow[t]{3}{*}{ Mléta Plain } & F00304388 & ENSEP Mostafa & 35.67028 & -0.63664 \\
\hline & & F00304209 & Sidi Maarouf & 35.68987 & -0.55121 \\
\hline & & F00303984 & O.T 3 & 35.57047 & -0.52977 \\
\hline & Ouled Taoui-Ouled Boudjemaâ & F00200039 & AT1 S.Djelloul & 35.34327 & -1.29686 \\
\hline \multirow[t]{12}{*}{ Macta } & \multirow[t]{2}{*}{ Melghir Plain } & F00404946 & MCID F & 35.15166 & -0.22513 \\
\hline & & G00300378 & Oued Sefioun & 35.05309 & -0.37729 \\
\hline & \multirow[t]{3}{*}{ Saida Plain } & F00301366 & Giroud leon & 35.11366 & 0.37005 \\
\hline & & G00400474 & Ain El Zerga & 34.85102 & 0.23819 \\
\hline & & F00400542 & Ain Soltane & 35.04471 & 0.38411 \\
\hline & \multirow[t]{2}{*}{ Ghriss Plain } & F00405234 & Matmore & 35.31868 & 0.2043 \\
\hline & & F00405236 & Roques EAC 1 & 35.27809 & 0.05016 \\
\hline & \multirow[t]{2}{*}{ High and medium of Mekerra wadi } & G00300440 & Telagh & 34.75939 & -0.56496 \\
\hline & & G00300341 & Tenira & 34.99907 & -0.54238 \\
\hline & \multirow[t]{3}{*}{ Sidi Bel Abbes Plain } & F00303939 & Sidi Lahcene & 35.17222 & -0.67382 \\
\hline & & F00304053 & Caid Belarbi & 35.15602 & -0.44275 \\
\hline & & G00300439 & Teghalimet & 34.85952 & -0.5652 \\
\hline \multirow[t]{12}{*}{ Tafna } & \multirow[t]{4}{*}{ Maghnia Plain } & G00200947 & Sehb El Aoud & 34.77309 & -1.7475 \\
\hline & & G00200942 & EAC EX Djaber & 34.84494 & -1.70878 \\
\hline & & G00200943 & Brazi AEK & 34.83559 & -1.82484 \\
\hline & & G00200945 & Station SNTF & 34.78863 & -1.80197 \\
\hline & \multirow[t]{8}{*}{ Mounts of Tlemcen } & G00200065 & Ain Bendou & 34.91207 & -1.27922 \\
\hline & & G00200941 & Sabra & 34.83224 & -1.55049 \\
\hline & & G00200488 & Ain Taga & 34.69395 & -1.31214 \\
\hline & & G00200759 & SafSaf & 34.91076 & -1.27121 \\
\hline & & G00200842 & Ain El Hout & 34.93176 & -1.32402 \\
\hline & & G00300211 & Ain Tellout & 34.92694 & -0.95871 \\
\hline & & G00300204 & Ain Isser & 34.82018 & -1.02579 \\
\hline & & G00300491 & Derman & 34.66871 & -1.25791 \\
\hline Chott Chergui & Chott Chergui & G00300523 & Ain Skhouna & 34.51367 & 0.76645 \\
\hline
\end{tabular}

parameter $(\mathrm{mg} / \mathrm{L})$ according to the guidelines of the WHO (2011) and Algerian Standards (OJAR 2011).

In the fourth step, the SI $i$ is first determined for each chemical parameter, which was then used to determine the WQI:

$S I_{i}=W_{i} * q_{i}$

The water quality index was calculated by adding together each subindex values of each groundwater samples as follows:

$\mathrm{WQI}=\sum S I_{i}$

where: $\mathrm{SI}_{i}$ is the subindex of the $i$ th parameter.

The computed WQI values are classified into five main classes: "excellent, good, poor, very poor and unfit water for drinking purposes," based on the absolute value of the index determined from the calculations. Water quality is classified as presented in Table 3.

The standards for drinking purposes as recommended by WHO (2011) and Algerian Standards have been considered for the calculation of WQI (cf. Table 2).

The WQI range and type of water can be classified as follows (cf. Table 3).

\section{Results and discussion}

\section{Physicochemical assessment}

The hydrochemical data set of the 32 locations is made up of a large number of samples gathered from January 2001 
Table 2 Weight and relative weight of each parameter used for the WQI calculation

\begin{tabular}{|c|c|c|c|c|}
\hline Parameter & Unit & Weight (wi) & $\begin{array}{l}\text { WHO standards } \\
\text { (2011) }\end{array}$ & $\begin{array}{l}\text { Relative weight } \\
(W i)\end{array}$ \\
\hline $\mathrm{pH}$ & & 4 & $6.5-8.5$ & 0.111 \\
\hline Calcium & $\mathrm{mg} / \mathrm{l}$ & 2 & 75 & 0.056 \\
\hline Magnesium & $\mathrm{mg} / \mathrm{l}$ & 1 & 50 & 0.028 \\
\hline Chloride & $\mathrm{mg} / \mathrm{l}$ & 3 & 250 & 0.083 \\
\hline Total dissolved solid & $\mathrm{mg} / \mathrm{l}$ & 5 & 500 & 0.139 \\
\hline Nitrate & $\mathrm{mg} / \mathrm{l}$ & 5 & $50^{\mathrm{a}}$ & 0.139 \\
\hline Conductivity & $\mu \mathrm{S} / \mathrm{cm}$ & 4 & 1500 & 0.111 \\
\hline Bicarbonate & $\mathrm{mg} / \mathrm{l}$ & 3 & 120 & 0.083 \\
\hline Potassium & $\mathrm{mg} / \mathrm{l}$ & 2 & 12 & 0.056 \\
\hline Phosphate & $\mathrm{mg} / \mathrm{l}$ & 1 & 5 & 0.028 \\
\hline Sodium & $\mathrm{mg} / \mathrm{l}$ & 2 & 200 & 0.056 \\
\hline \multirow[t]{2}{*}{ Sulfate } & $\mathrm{mg} / \mathrm{l}$ & 4 & 250 & 0.111 \\
\hline & & $\sum w_{i}=36$ & & $\sum \mathrm{W} i=1$ \\
\hline
\end{tabular}

${ }^{a}$ Official Journal of Algerian Republic (OJAR 2011)
Table 3 Water quality classification based on WQI values (Sahu and Sikdar 2008)

\begin{tabular}{cll}
\hline WQI range & Class & Type of water \\
\hline$<50$ & I & Excellent water \\
$50-100$ & II & Good water \\
$100-200$ & III & poor water \\
$200-300$ & IV & Very poor water \\
$>300$ & V & Unsuitable for drinking \\
\hline
\end{tabular}

to December 2006. The values of $\mathrm{pH}$ are within the permissible limit for all groundwater samples. The chlorides contents were high in all areas except in Ain el Zerga, Matmore, Roques EAC 1, Telagh, Caid Belarbi, Teghalimet, Ain Bendou, Sabra, Ain Taga, SafSaf, Ain el Hout, Ain Tellout, Ain Isser, Derman and Ain Skhouna. The quality of groundwater of Ain Taga station (G00200488) was better compared to other stations, and hence, it scored the best. Total dissolved solids varied from 400 to $6400 \mathrm{mg} / \mathrm{l}$, and the highest TDS concentrations are observed at the station of Bredeah.

Total hardness, $\mathrm{Ca}$ and $\mathrm{Mg}$ hardness were found to be high in the station of Bredeah, ENSEP Mostafa, Sidi Maarouf, O.T 3, AT1 S.Djelloul and Sidi Lahcene. The high levels of chlorides, TDS and hardness are observed at stations: Ain Turk, EAC N7, station of Bredeah, ENSEP Mostafa, Sidi Maarouf, O.T 3, AT1 S.Djelloul, MCID F 37, Oued Sefioun, Giroud Leon, Ain el Zerga, Ain Soltane, Matmore, Roques EAC 1, Telagh, Tenira, Sidi Lahcene, Caid Belarbi, Teghalimet, Sehb el Aoud, EAC Ex Djaber and Brazi AEK; this may be due to the geological formation of the area. The minerals of the soil and rock get dissolve in the groundwater, leading to high concentrations of dissolved solids. Sulfate was less in many areas except for two stations (Bredeah and ENSEP Mostafa).

\section{Hydrogeochemical facies}

There is a need for comparing the origins and distributions of groundwater masses that have different geochemical attributes by means of graphical representations. The Piper (1944) diagram is very useful to delineate variability and trends in water quality; it has contributed extensively to the understanding of groundwater flow and geochemistry (Dalton and Upchurch 1978). In order to determine chemical relationships and geochemical evolution of some aquifers, Piper diagram of groundwater quality parameters monitored at sampling sites which present a worst-case condition was plotted and is shown in Fig. 3. The plot of chemical data on diamond-shaped trilinear diagram reveals that majority of the groundwater samples of Mléta Plain and Coastal Oranais Plain (Ain Turk, EAC N7, station of Bredeah, ENSEP Mostafa, Sidi Maarouf and O.T 3) in almost all the years fall in the $\mathrm{Na}+\mathrm{K} \_\mathrm{Cl}+\mathrm{SO}_{4}$ type, indicating the influence of saltwater intrusion in these wells. For Melghir Plain and Maghnia Plain aquifers, Piper diagram shows that the dominant water types in these aquifers are in the order of mixed $\mathrm{Ca}-\mathrm{Mg}-\mathrm{Cl}>\mathrm{Ca}-\mathrm{Cl}$. The vast majority of samples are mixed $\mathrm{Ca}-\mathrm{Mg}-\mathrm{Cl}$-dominant fluids. It indicates mixing of high-salinity water caused from surface contamination sources, domestic wastewater and irrigation return flow with existing water followed by ion exchange process (ABHOCC 2009a, b; Adjim and Bensaoula 2013). However, $\mathrm{Ca}-\mathrm{Cl}$ water types suggest mineral dissolution, an interaction between rock and water and recharge of freshwater (Selvakumar et al. 2017). 
Fig. 3 Piper trilinear diagram for hydrogeochemical facies of some aquifers in the study area

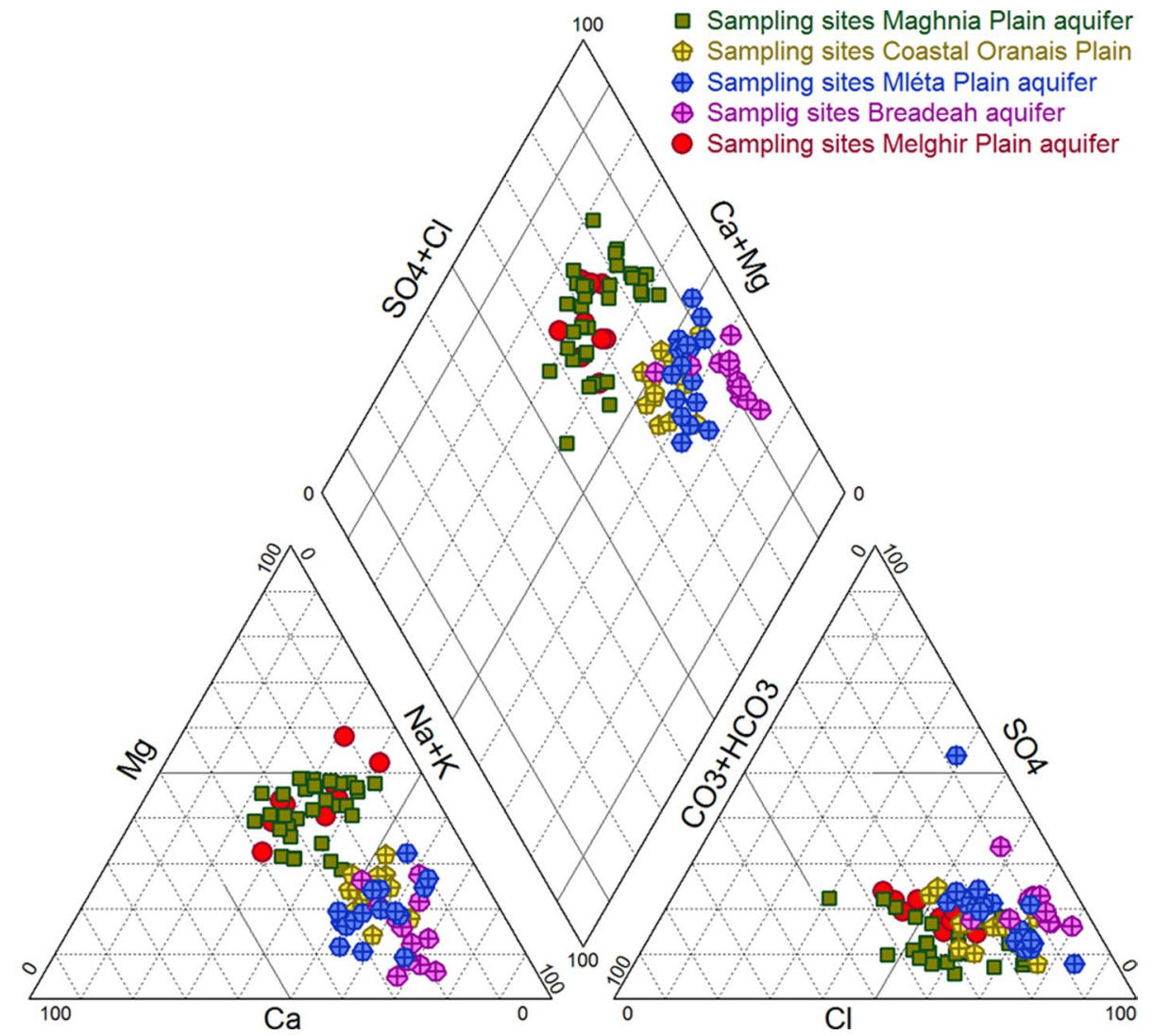

\section{Multivariate statistical analysis}

Multivariate statistical techniques have been extensively used to facilitate the solution to environmental problems and suggest evidence for the understanding of some natural and anthropogenic processes (Singh et al. 2005). Principal component analysis (PCA) and correlation analysis (CA) were employed in this study to identify parameters influencing geochemical processes in the aquifer system. Multivariate analysis was performed using KyPlot 5.0 software. Given the large number of studied aquifers (12 aquifers) and to reduce the volume of information needed for the evaluation of the quality of some aquifers, Bredeah aquifer has been selected in this paper, as an example. Correlation matrix is given in Table 4; it is observed that the EC shows a high positive correlation with $\mathrm{Cl}^{-}, \mathrm{SO}_{4}{ }^{2-}, \mathrm{K}^{+}, \mathrm{Ca}^{2+}$ and $\mathrm{Na}^{+}$and moderate correlation with $\mathrm{HCO}_{3}{ }^{-}$and $\mathrm{NO}_{3}{ }^{-}$. The existence of strong positive correlation of $\mathrm{Na}^{+}$and $\mathrm{Cl}^{-}(0.917)$ and

Table 4 Correlation matrix for groundwater samples in station of Bredeah

\begin{tabular}{|c|c|c|c|c|c|c|c|c|c|c|c|c|}
\hline & $\mathrm{Ca}$ & $\mathrm{Cl}$ & $\mathrm{EC}$ & $\mathrm{HCO}_{3}$ & $\mathrm{~K}$ & $\mathrm{Mg}$ & $\mathrm{Na}$ & $\mathrm{NO}_{3}$ & $\mathrm{pH}$ & $\mathrm{PO} 4$ & TDS & $\mathrm{SO}_{4}$ \\
\hline $\mathrm{Ca}$ & 1 & & & & & & & & & & & \\
\hline $\mathrm{Cl}$ & 0.697 & 1 & & & & & & & & & & \\
\hline $\mathrm{EC}$ & 0.823 & 0.857 & 1 & & & & & & & & & \\
\hline $\mathrm{HCO}_{3}$ & 0.783 & 0.619 & 0.672 & 1 & & & & & & & & \\
\hline $\mathrm{K}$ & 0.649 & 0.852 & 0.747 & 0.807 & 1 & & & & & & & \\
\hline $\mathrm{Mg}$ & 0.073 & 0.645 & 0.433 & 0.318 & 0.658 & 1 & & & & & & \\
\hline $\mathrm{Na}$ & 0.818 & 0.917 & 0.907 & 0.814 & 0.911 & 0.499 & 1 & & & & & \\
\hline $\mathrm{NO}_{3}$ & 0.662 & 0.282 & 0.448 & 0.38 & 0.151 & -0.054 & 0.395 & 1 & & & & \\
\hline $\mathrm{pH}$ & -0.756 & -0.624 & -0.801 & -0.494 & -0.575 & -0.157 & -0.758 & -0.505 & 1 & & & \\
\hline $\mathrm{PO}_{4}$ & -0.664 & -0.675 & -0.793 & -0.492 & -0.408 & -0.373 & -0.646 & -0.589 & 0.554 & 1 & & \\
\hline TDS & -0.229 & -0.146 & -0.251 & -0.234 & 0.041 & -0.041 & -0.142 & -0.257 & 0.142 & 0.667 & 1 & \\
\hline $\mathrm{SO}_{4}$ & 0.648 & 0.717 & 0.827 & 0.811 & 0.845 & 0.478 & 0.889 & 0.228 & -0.634 & -0.522 & -0.108 & 1 \\
\hline
\end{tabular}


weak positive correlation between $\mathrm{Ca}^{2+}$ and $\mathrm{Mg}^{2+}$ indicates these parameters have mixed sources of the origin (BodrudDoza et al. 2016). The relationship between $\mathrm{Na}^{+}$and $\mathrm{Cl}^{-}$has been used to identify the process that controls the salinity and saline intrusion in arid and semiarid areas (Singh et al. 2005; Sheikhy Narany et al. 2014).

The PCA results comprising the loadings, eigenvalues and percentage of total variance are summarized in Table 5. PCA extracts correlations and reduces the number of data into components that explain a portion of the total variance between chemical parameter. It indicates that the first three principal components together account for $85.54 \%$ of the total variance in the data set, in which the first principal component is $61.27 \%$, second principal component is $14.69 \%$, and the third principal component is $9.57 \%$ of the total variance. The concentrations of $\mathrm{Ca}^{2+}$, $\mathrm{Cl}^{-}, \mathrm{EC}, \mathrm{HCO}_{3}{ }^{-}, \mathrm{K}^{+}, \mathrm{SO}_{4}{ }^{2-}$ and $\mathrm{Na}^{+}$show high positive loadings (0.825-0.975), whereas concentrations of $\mathrm{Mg}^{2+}$ and $\mathrm{NO}_{3}{ }^{-}$have moderate positive loadings $(0.498-0.500)$ for the first principal component. In the second principal component, TDS and Mg concentrations have moderate positive loadings (0.556-0.614) and the concentrations of $\mathrm{Cl}^{-}$, $\mathrm{HCO}_{3}{ }^{-}, \mathrm{K}^{+}, \mathrm{Na}^{+}, \mathrm{pH}, \mathrm{PO}_{4}{ }^{3-}$ and $\mathrm{SO}_{4}{ }^{2-}$ show low positive loading (0.054-0.460). For the third principal component, the concentrations of TDS show moderate positive loadings (0.644) and the concentrations of $\mathrm{Ca}^{2+}, \mathrm{PO}_{4}{ }^{3-}, \mathrm{NO}_{3}{ }^{-}$, $\mathrm{HCO}_{3}{ }^{-}, \mathrm{Na}^{+}, \mathrm{SO}_{4}{ }^{2-}$ and $\mathrm{K}^{+}$show low positive loadings (0.049-0.403).

The high positive loadings of $\mathrm{Ca}^{2+}, \mathrm{Cl}^{-}, \mathrm{EC}, \mathrm{HCO}_{3}{ }^{-}, \mathrm{K}^{+}$, $\mathrm{SO}_{4}{ }^{2-}$ and $\mathrm{Na}^{+}$ions on the first principal component suggest that the first principal component is associated with

Table 5 Rotated factor loadings for groundwater samples in station of Bredeah

\begin{tabular}{lcrr}
\hline Parameter & \multicolumn{3}{l}{ Factor } \\
\cline { 2 - 4 } & \multicolumn{1}{c}{2} & \multicolumn{1}{c}{3} \\
\hline $\mathrm{Ca}$ & 0.866 & -0.296 & 0.313 \\
$\mathrm{Cl}$ & 0.895 & 0.216 & -0.142 \\
$\mathrm{EC}$ & 0.948 & -0.050 & -0.006 \\
$\mathrm{HCO} 3$ & 0.825 & 0.054 & 0.119 \\
$\mathrm{~K}$ & 0.862 & 0.460 & 0.049 \\
$\mathrm{Mg}$ & 0.500 & 0.556 & -0.533 \\
$\mathrm{Na}$ & 0.975 & 0.144 & 0.076 \\
$\mathrm{NO} 3$ & 0.498 & -0.645 & 0.237 \\
$\mathrm{pH}$ & -0.781 & 0.182 & -0.297 \\
$\mathrm{PO} 4$ & -0.766 & 0.439 & 0.403 \\
$\mathrm{TDS}$ & -0.272 & 0.614 & 0.644 \\
SO4 & 0.870 & 0.250 & 0.056 \\
Eigenvalue & 7.352 & 1.763 & 1.148 \\
\% Total variance & 61.27 & 14.69 & 9.57 \\
Cumulative \% variance & 61.27 & 75.96 & 85.54 \\
\hline
\end{tabular}

a combination of various hydrogeochemical processes and augment more mineralized water. For instance, a high positive loading of $\mathrm{Na}^{+}$ion suggests ion exchange on the clay materials. The process of dissolution of $\mathrm{Na}^{+}$and $\mathrm{Cl}^{-}$ions indicates a higher rate of weathering in the area (Bhardwaj et al. 2010; Agoubi et al. 2014).

The concentration of $\mathrm{HCO}_{3}{ }^{-}$and $\mathrm{pH}$ of groundwater are the results of the reaction of soil $\mathrm{CO}_{2}$ with the dissolution of silicate minerals (Krantzberg et al. 2010). Generally, mineral dissolution during water-rock interaction depends on the amount of $\mathrm{CO}_{2}$ gas, originated from $\mathrm{H}_{2} \mathrm{CO}_{3}$. Thus, mineral saturation in groundwater depends on the amount of $\mathrm{pCO}_{2}$ value, the amount of $\mathrm{Ca}^{2+}, \mathrm{CO}_{2}, \mathrm{HCO}_{3}{ }^{-}$species and $\mathrm{H}_{2} \mathrm{CO}_{3}$ concentration. A decrease in the partial $\mathrm{CO}_{2}$ and $\mathrm{H}_{2} \mathrm{CO}_{3}$ values during outgassing of $\mathrm{CO}_{2}$ results in an increase in $\mathrm{HCO}_{3}{ }^{-}$and $\mathrm{pH}$ levels (Ozler 2003).

\section{WQI for drinking water assessment}

The suitability of groundwater of Northwestern Algeria aquifers for human drinking purpose was achieved using WQI. The selection of the parameters that will make up the index depends on several factors, such as the purpose of the index, the importance of the parameter and the availability of data. The computed WQI values range from 67 to 588 and therefore can be categorized into four categories: "good water" to "water unsuitable for drinking."

Overall, $36 \%$ of groundwater sites sampled in the study area had good water quality, while $53 \%$ were poor. The majority had fair quality. Unfortunately, $6 \%$ of the samples indicate "very poor water quality" and 5\% represent "water unsuitable for drinking purposes" (cf. Table 6). This may be due to extensive aquifer exploitation, the intrusion of saline waters or other poor quality water into the freshwater zones of aquifers (e.g., Coastal Oranais Plain), irrigation return flow, the impact of natural sources of contamination (geology of rocks, weathering of rocks, etc.) and anthropogenic activities (ABHOCC 2009a, b; ABHOCC 2012). Furthermore, the groundwater quality of some aquifers was likely affected by the drought in different ways; the last drought period has contributed significantly to the degradation of groundwater quality as a result of the overuse of aquifers (Iglesias et al. 2006b; Adjim and Bensaoula 2013).

Results show that the majority of groundwater of Tafna basin fell under good water quality, except samples of Ain el Hout (mounts of Tlemcen aquifer), Sehb El Aoud, EAC Ex Djaber, Brazi AEK and station SNTF (Maghnia Plain aquifer) which fell under poor water quality.

Groundwater of poor and medium quality characterizes the majority of the studied aquifers of Macta basin. The results showed that the water quality at monitoring station "Ain Skhouna" fell under good water quality (Chott Chergui aquifer). 
Table 6 Groundwater classification based on WQI

\begin{tabular}{|c|c|c|c|c|c|c|}
\hline \multirow[t]{2}{*}{ Aquifer } & \multirow[t]{2}{*}{ Station ID } & \multirow[t]{2}{*}{ Station name } & \multicolumn{4}{|l|}{ WQI } \\
\hline & & & 2001 & 2004 & 2005 & 2006 \\
\hline \multirow[t]{2}{*}{ Coastal Oranais Plain } & F00300743 & Ain Turk & 168.45 & 121.38 & 162.90 & 148.11 \\
\hline & F00302668 & EAC N7 & 146.37 & 134.47 & 137.44 & 139.38 \\
\hline Bredeah Plain & F00304207 & Station of Bredeah & 223.73 & 478.77 & 588.27 & 538.93 \\
\hline \multirow[t]{3}{*}{ Mléta Plain } & F00304388 & ENSEP Mostafa & 211.88 & & 213.84 & 211.44 \\
\hline & F00304209 & Sidi Maarouf & 219.39 & 170.71 & 183.55 & 187.10 \\
\hline & F00303984 & O.T 3 & 178.25 & 182.93 & 180.25 & \\
\hline Ouled Taoui-Ouled Boudjemaâ & F00200039 & AT1 S.Djelloul & 137.47 & 140.13 & 153.91 & \\
\hline \multirow[t]{2}{*}{ Melghir Plain } & F00404946 & MCID F & & & 155.92 & 145.76 \\
\hline & G00300378 & Oued Sefioun & & & 165.27 & 160.27 \\
\hline \multirow[t]{3}{*}{ Saida Plain } & F00301366 & Giroud leon & 469.04 & & & \\
\hline & G00400474 & Ain El Zerga & 82.62 & 78.59 & 76.80 & 82.39 \\
\hline & F00400542 & Ain Soltane & 128.03 & 111.75 & 153.27 & 127.64 \\
\hline \multirow[t]{2}{*}{ Ghriss Plain } & F00405234 & Matmore & 110.62 & 82.93 & 86.10 & \\
\hline & F00405236 & Roques EAC 1 & & 109.28 & 109.76 & 113.71 \\
\hline \multirow[t]{2}{*}{ High and medium of Mekerra wadi } & G00300440 & Telagh & & & 92.18 & 86.28 \\
\hline & G00300341 & Tenira & & & 143.24 & 141.68 \\
\hline \multirow[t]{3}{*}{ Sidi Bel Abbes Plain } & F00303939 & Sidi Lahcene & & & 95.83 & \\
\hline & F00304053 & Caid Belarbi & & & 97.10 & 93.29 \\
\hline & G00300439 & Teghalimet & & & 140.22 & 134.23 \\
\hline \multirow[t]{4}{*}{ Maghnia Plain } & G00200947 & Sehb El Aoud & 121.27 & 98.96 & 89.81 & 74.55 \\
\hline & G00200942 & EAC EX Djaber & 132.51 & 126.54 & 105.14 & 113.17 \\
\hline & G00200943 & Brazi AEK & 159.81 & 153.88 & 152.14 & 155.44 \\
\hline & G00200945 & Station SNTF & 126.83 & 106.69 & 114.06 & 118.54 \\
\hline \multirow[t]{8}{*}{ Mounts of Tlemcen } & G00200065 & Ain Bendou & 92.75 & & 83.56 & 88.07 \\
\hline & G00200941 & Sabra & & 96.79 & 81.78 & 82.10 \\
\hline & G00200488 & Ain Taga & & & 67.83 & 69.95 \\
\hline & G00200759 & SafSaf & 82.11 & 79.93 & 78.03 & 82.07 \\
\hline & G00200842 & Ain El Hout & 112.85 & 101.65 & 101.93 & 109.05 \\
\hline & G00300211 & Ain Tellout & & & 82.58 & 86.47 \\
\hline & G00300204 & Ain Isser & & & 76.79 & 77.53 \\
\hline & G00300491 & Derman & & & 82.51 & 92.50 \\
\hline Chott Chergui & G00300523 & Ain Skhouna & & & 91.39 & 81.47 \\
\hline
\end{tabular}

The results also show that groundwater of Coastal Oranais basin showed poor water quality, a very poor at "ENSEP Mostafa" station and unsuitable for drinking purposes at station of Bredeah (cf. Table 6).

Figure 4 presents the spatial distribution map of the water quality index; this map can be used as a tool for environmental decision-making process. It shows that the sampling sites with poor, very poor and unsuitable categories coincide with the sites in which groundwater quality criteria are exceeded.

\section{Groundwater quality analysis of Bredeah: case study}

Bredeah station is situated at $25 \mathrm{~km}$ southwest of Oran city. Groundwater of Bredeah flows through two superimposed formations: Fresh groundwater is present in the Miocene limestone; brackish groundwater is pumped from the PlioQuaternary aquifer. Groundwater pumping from Bredeah causes lowering of the water table by more than $7 \mathrm{~m}$ and has also caused saltwater intrusion from the adjacent Sebkha (Great saline lake with an area of $310 \mathrm{Km}^{2}$ ) (Dahmani and Bithorel 2001). Salinity levels are generally highest where they exceed $7 \mathrm{~g} / \mathrm{l}$. Indeed, conductivity values are between 1690 and $9370 \mu \mathrm{S} / \mathrm{cm}$ and chloride ions contents are ranging between 370 and $3618 \mathrm{mg} / \mathrm{l}$. High concentrations of chloride, sodium and EC followed by calcium clearly indicate that rock-water interaction process is among the main causes of the deterioration of groundwater quality. In order to exploit the groundwater of Bredeah, a demineralization plant has been built in this site since 2005; it produces 35,000 cubic meters of desalted water per day to meet a part of the water needs of Oran Metropolis. However, in others

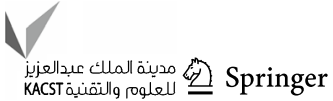




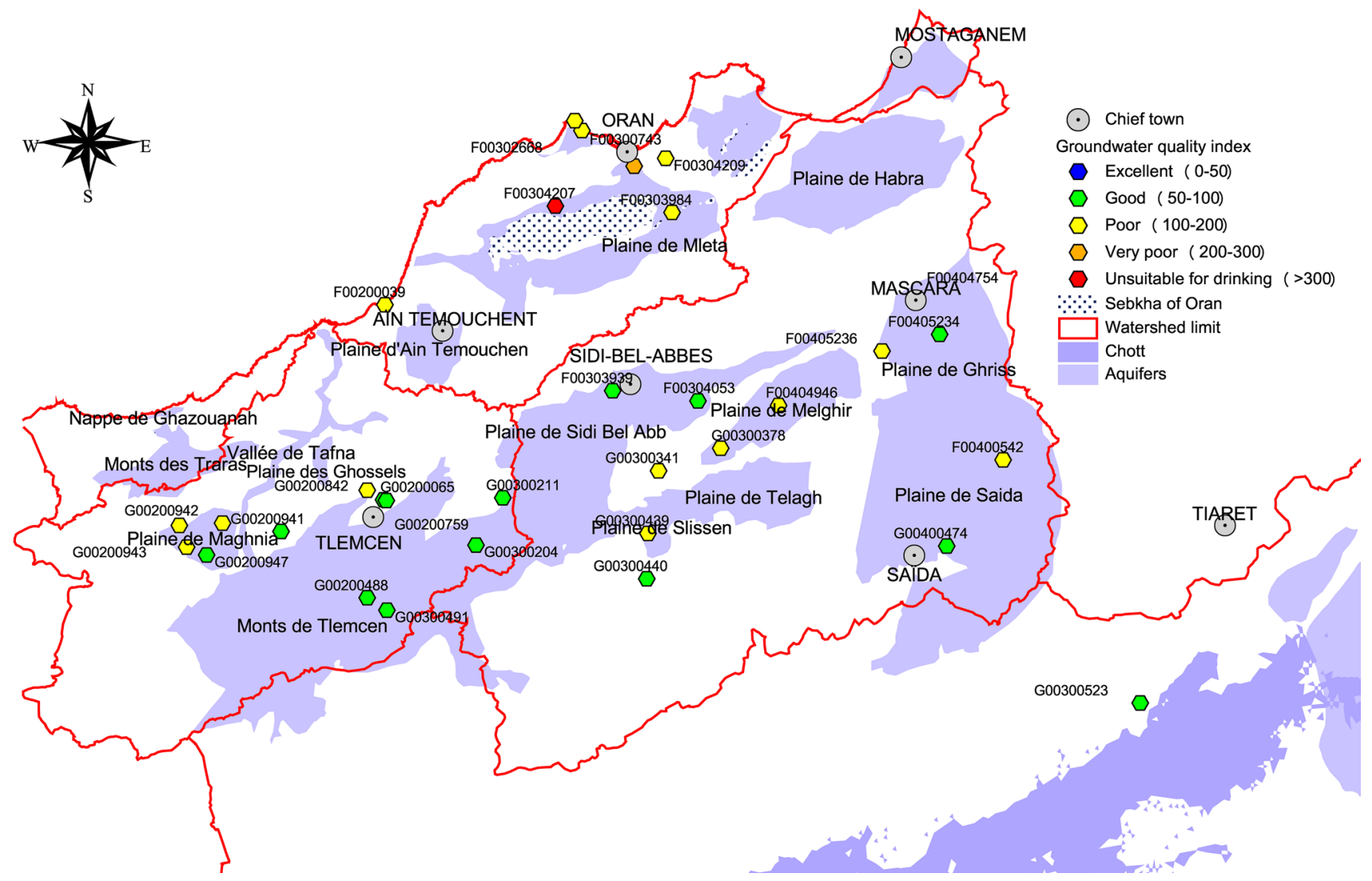

Fig. 4 Spatial map for groundwater quality index in Northwestern Algeria for the year 2005

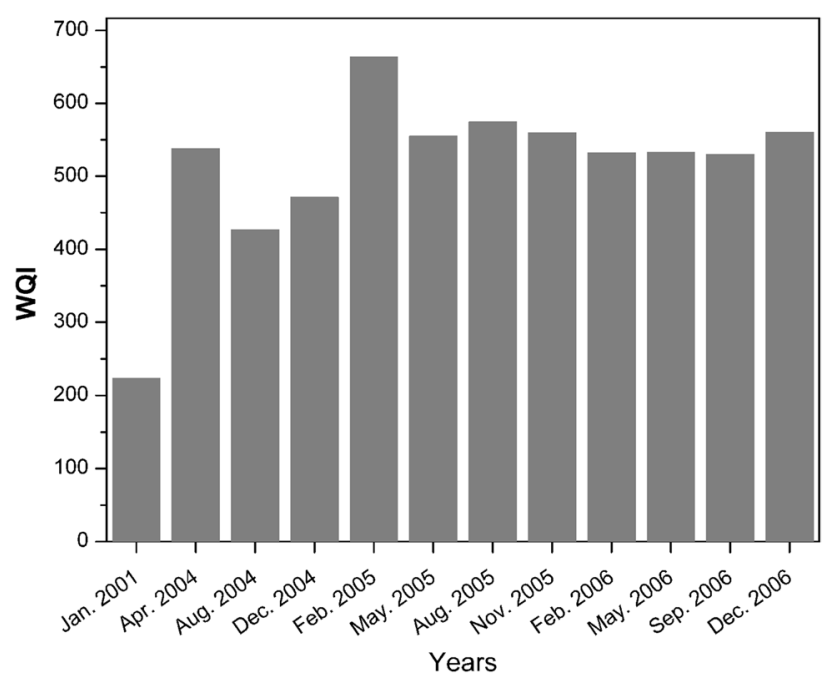

Fig. 5 Trend of WQI "station of Bredeah"

cities, this water is used without any prior treatments (Hadji et al. 2010).

Figure 5 shows the trend of water quality index at monitoring station of Bredeah; the status results indicated that the water quality showed a trend of degradation. As shown in
Fig. 5, the variation in the WQI at Bredeah is falling in the range of 224 and 663, which is also high. High WQI variations are found in April 2004 and Feb 2005; the average water quality conditions remain the same during the period of May 2005 to December 2006.

The actual groundwater status has not changed significantly compared to the study period; the Hydrographical Basin Agency's reports have revealed that the actual situation of groundwater has been marked by continuous decreases in water quality caused by the synergistic effects of drought, changing land use, pollution from agriculture and industrialization, as well as from natural processes (weathering of soil and rock) (ABHOCC 2009a, b, 2012, 2016). Current groundwater use practices have led to overexploitation of some aquifers in Tafna basin (e.g., aquifer of Maghnia); some aquifers in the Coastal Oranais basin have also not escaped overexploitation with the Bredeah and Coastal Oranais Plain aquifers suffering from saltwater intrusion (Dahmani and Bithorel 2001; Gaaloul et al. 2012; Adjim and Bensaoula 2013; Boubaya 2017; Alfarrah and Walraevens 2018). The continuous monitoring of groundwater is required to get the recent groundwater quality status to check any possible contamination in future due to growing industrialization and agricultural activities; the influence of 
salt water on the some freshwater aquifers in the study area needs special attention in terms of monitoring and for sustainable management.

Experience has shown that effective strategies for better water resources management consistently include some common features. Good practices almost certainly involve, to one extent or another, the following elements:

- Improving understanding and management of groundwater resources; poor management is linked to the poor knowledge of the resource, the proliferation of illicit wells, and poor coordination and collaboration between some of the bodies with responsibility for groundwater (ANRH, Hydrographical Basin Agencies "ABH," National office of Irrigation and Drainage "ONID," water resource departments of wilayas "DREW").

- Integration of remote sensing and GIS techniques with classic geological and hydrogeological exploration methods provides a better platform for improving data collection and its use for better understanding and managing groundwater resources.

- New laws are now designed to increase protection for groundwater resources. The new laws (Water Law 2005 and 2008) aim to strengthen and clarify certain provisions for new abstraction and the operation, management, maintenance and preservation of infrastructure. The new measures have been adopted to vigorously fight against any infringement of water legislation (Official Journal of Algerian Republic 2005).

- Improve groundwater monitoring network; groundwater resources assessment and management are hampered considerably by a lack of data, especially in semiarid and arid environments with a weak observation infrastructure (Brunner et al. 2006). There is a monitoring network operated by the ANRH, but it remains insufficient, especially with regard to the monitoring network for groundwater that does not obey all the conditions for a good network (MRE 2010).

\section{Conclusion}

In this study, the use of prominent tools and techniques for interpreting water quality is demonstrated by applying them to groundwater quality data of some aquifers in Northwestern Algeria. Water quality index and multivariate statistics methods are applied to characterize water quality, which is a major factor for controlling the groundwater quality in term of drinking purposes. The results point out that the majority of the groundwater samples of Mléta Plain and Coastal Oranais Plain in almost all the years fall in the $\mathrm{Na}+\mathrm{K} \_\mathrm{Cl}+\mathrm{SO}_{4}$ type indicating the influence of saltwater intrusion in these wells. The computed water quality index values range from
67 to 588 and therefore can be categorized into four categories: "good water" to "water unsuitable for drinking." Overall, $36 \%$ of groundwater sites sampled in the study area had good water quality, while $53 \%$ were poor. The majority had fair quality. Unfortunately, $6 \%$ of the samples indicate "very poor water quality" and 5\% represent "water unsuitable for drinking purposes."

The results show that the majority of groundwater of Tafna basin fell under good water quality, except some stations in mounts of Tlemcen aquifer and Maghnia Plain aquifer which fell under poor water quality. Groundwater of poor and medium quality characterizes the majority of the studied aquifers of Macta basin. The results showed that the water quality at monitoring station "Ain Skhouna" fell under good water quality (Chott Chergui aquifer). Results also show that groundwater of Coastal Oranais basin showed poor water quality, a very poor at some monitoring stations of Mléta Plain aquifer.

It has been demonstrated that the water of some aquifers has degraded under water scarcity conditions and will continue to degrade given the ongoing and projected development in the study area. The influence of salt water on the some freshwater aquifers in the study area needs special attention in terms of monitoring and for sustainable management. A re-evaluation of the WQI based on recent data will be very useful in the management of groundwater resources in the region.

Acknowledgements The authors wish to acknowledge the staff of ABHOCC and ANRH agencies for their assistance in providing facilities for the completion of this research. The authors would also like to thank the anonymous reviewers for their valuable comments and suggestions.

Open Access This article is distributed under the terms of the Creative Commons Attribution 4.0 International License (http://creativeco mmons.org/licenses/by/4.0/), which permits unrestricted use, distribution, and reproduction in any medium, provided you give appropriate credit to the original author(s) and the source, provide a link to the Creative Commons license, and indicate if changes were made.

\section{References}

Abbasi T, Abbasi SA (2012) Water-quality indices. Water Quality Indices. https://doi.org/10.1016/b978-0-444-54304-2.00016-6

Agence de Bassin Hydrographique Oranais Chott Chergui (ABHOCC) (2006a) Hydraulic cadastre, Macta Basin. Synthesis report. Ministry of water resources, Algiers (in French)

ABHOCC (2006b) Hydraulic cadastre, Tafna Basin. Synthesis report. Ministry of water resources, Algiers (in French)

ABHOCC (2006c) Hydraulic cadastre, Costal Oranais Basin. Synthesis report. Ministry of water resources, Algiers (in French)

ABHOCC (2009a) Developing the pollution sources map for monitoring and preservation the water quality resources of Tafna

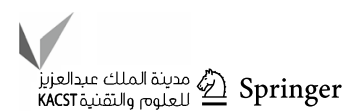


and Coastal Oranais basins. Synthesis report. Ministry of water resources (in French)

ABHOCC (2009b) Identification and mapping of points discharges of domestic and industrial waste water in the Tafna basin. Synthesis report. Ministry of water resources, Algiers (in French)

ABHOCC (2012) Identification and mapping of points discharges of domestic and industrial waste water in the Costal Oranais basin. Final report. Ministry of water resources, Algiers (in French)

ABHOCC (2016) Water quality. http://www.abhoranie.dz/quali te.html. Accessed 12 Aug 2018 (in French)

Adjim M, Bensaoula F (2013) Application of the DRASTIC groundwater vulnerability mapping to the aquifer of Maghnia (North-West of Algeria). LARHYSS J 16:21-30

Agoubi B, Kharroubi A, Abida H (2014) Geochemical assessment of environmental impact on groundwater quality in coastal arid area, South Eastern Tunisia. J Environ Sci Eng Technol 2(2):35-46. https://doi.org/10.12974/2311-8741.2014.02.02.2

Alfarrah N, Walraevens K (2018) Groundwater overexploitation and seawater intrusion in coastal areas of arid and semi-arid regions. Water 10(2):143. https://doi.org/10.3390/w10020143

Backman B, Bodiš D, Lahermo P et al (1998) Application of a groundwater contamination index in Finland and Slovakia. Environ Geol 36(1-2):55-64. https://doi.org/10.1007/s002540050320

Bekkoussa B, Meddi M, Jourde H (2008) Climatic and anthropic forcing on groundwater resources in a semiarid area: The case of the Ghriss plain, north western Algeria. Sécheresse 19(3):173 (in French)

Bhardwaj V, Singh DS, Singh AK (2010) Water quality of the Chhoti Gandak River using principal component analysis, Ganga Plain, India. J Earth Syst Sci 119(1):117-127. https://doi.org/10.1007/ s12040-010-0007-8

Bodrud-Doza M, Islam ARMT, Ahmed F et al (2016) Characterization of groundwater quality using water evaluation indices, multivariate statistics and geostatistics in central Bangladesh. Water Sci 30(1):19-40. https://doi.org/10.1016/j.wsj.2016.05.001

Boubaya D (2017) Combining resistivity and aeromagnetic geophysical surveys for groundwater exploration in the Maghnia Plain of Algeria. J Geol Res 2017:1-14. https://doi.org/10.1155/2017/1309053

Brown RM, McClelland NI, Deininger RA, Tozer RG (1970) A water quality index: do we dare? Water Sew Works 117:339-343

Brunner P, Hendricks Franssen HJ, Kgotlhang L, Bauer-Gottwein P, Kinzelbach W (2006) How can remote sensing contribute in groundwater modeling? Hydrogeol J 15(1):5-18. https://doi. org/10.1007/s10040-006-0127-z

Dahmani B, Bithorel C (2001) Déminéralisation des eaux saumâtres de Brédéah dans la région du bassin hydrographique OranieChott-Chergui, Partie I: hydrogéologie de la nappe de Brédéah. Desalination 137(1-3):297-309. https://doi.org/10.1016/s0011 $-9164(01) 00232-6$

Dalton MG, Upchurch SB (1978) Interpretation of hydrochemical facies by factor analysis. GroundWater 16:228-233. https://doi. org/10.1111/j.1745-6584.1978.tb03229.x

FAO (2009) Groundwater management in Algeria. Draft synthesis Report. Food and agriculture organization of the United Nations. Rome

Gaaloul N, Pliakas F, Kallioras A, Schuth C, Marinos P (2012) Simulation of seawater intrusion in coastal aquifers: forty five-years exploitation in an Eastern Coast Aquifer in NE Tunisia. Open Hydrol J 6(1):31-44. https://doi.org/10.2174/187437810120601 0031

Hadji F, Marok A, Belmouhoub A et al (2010) Water resources and its quality in arid and semi-arid areas: the case of the NW of Algeria. J Black Sea/Medit Environ 16(1):75-85

Hamlat A, Errih M, Guidoum A (2013) Simulation of water resources management scenarios in western Algeria watersheds using WEAP model. Arab J Geosci 6(7):2225-2236
Horton RK (1965) An index number system for rating water quality. J Water Pollut Control Feder 37(3):300-306

Iglesias A, Garrote L, Flores F, Moneo M (2006a) Challenges to Manage the Risk of Water Scarcity and Climate Change in the Mediterranean. Water Resour Manag 21(5):775-788. https://doi. org/10.1007/s11269-006-9111-6

Iglesias A, Garrote L, Flores F, Moneo M (2006b) Challenges to manage the risk of water scarcity and climate change in the mediterranean. Water Resour Manag 21(5):775-788. https://doi. org/10.1007/s11269-006-9111-6

Jinturkar AM, Deshmukh SS, Agarkar SV, Chavhan GR (2010) Determination of water quality index by fuzzy logic approach: a case of ground water in an Indian town. Water Sci Technol 61(8):1987-1994

Kasim M, Roslan M, Yusoff MK et al (2007) Creation of a ground water quality index for an open municipal landfill area. Malays J Math Sci 1(2):181-192

Ketata M, Gueddari M, Bouhlila R (2011) Use of geographical information system and water quality index to assess groundwater quality in El Khairat deep aquifer (Enfidha, Central East Tunisia). Arab J Geosci 5(6):1379-1390. https://doi.org/10.1007/s1251 7-011-0292-9

Kortatsi B (2009) Geochemical assessment of springs in the Ho District of Ghana using multivariate statistical technique. West Afr J Appl Ecol. https://doi.org/10.4314/wajae.v7i1.45636

Krantzberg G, Tanik A, do Carmo JSA et al (2010) Advances in water quality control. Scientific Research Publishing, Inc, USA

Masih I, Maskey S, Mussá FEF, Trambauer P (2014) A review of droughts in the African continent: a geospatial and long-term perspective. Hydrol Earth Syst Sci 11(3):2679-2718. https://doi. org/10.5194/hessd-11-2679-2014

Meddi M, Hubert P (2003) Impact of rainfall regime change on water resources in Northwestern Algeria. Hydrol Mediterr Semiarid Reg 278:229-235

Ministère des Ressources en Eau (MRE) (2009) Water resources master plans of Oranie - Chott Chergui, Synthesis report. Ministry of Water Resources. Algiers (in French)

Ministère des Ressources en Eau (MRE) (2010) Study on updating the national water plan. EuropeAidEuropeAid/126155/D/SER/ DZ. Programme MEDA de l'Union Européenne. Groupement SOFRECO - Grontmij/Carl Bro - Progress - OIEau February 2010 (in French)

Mitiche R, Metaiche M, Kettab A et al (2010) Desalination in Algeria: current situation and development programs. Desalin Water Treat 14(1-3):259-264

Official Journal of the Algerian Republic (OJAR) (2005) The law $n^{\circ} 05$ 12 of August 04th, 2005 relative to the water. OJAR, Algeria in French

Official Journal of the Algerian Republic (OJAR) (2011) The guidelines for Algerian drinking water quality. OJAR, Algeria in French

Ozler MH (2003) Hydrochemistry and salt-water intrusion in the Van aquifer, east Turkey. Environ Geol 43(7):759-775. https://doi. org/10.1007/s00254-002-0690-0

Pei-Yue L, Hui Q, Jian-Hua WU (2010) Groundwater quality assessment based on improved water quality index in Pengyang County, Ningxia, Northwest China. J Chem 7(s1):S209-S221. https://doi. org/10.1155/2010/451304

Piper AM (1944) A graphical procedure in the geochemical interpretation of water analysis. Trans Am Geophys Union 25:914-928

Queralt E, Pastor JJ, Corp RM, Galofre A (2008) Economic index of quality for ground water (IEQAS) based on the potabilisation treatment cost. Practical application to aquifers in Catalonia. Tecnol Agua 28(293):89-94

Ravikumar P, Mehmood MA, Somashekar RK (2013) Water quality index to determine the surface water quality of Sankey tank and 
Mallathahalli Lake, Bangalore urban district, Karnataka, India. Appl Water Sci 3(1):247-261. https://doi.org/10.1007/s1320 $1-013-0077-2$

Sadi A (2004) Seawater desalination share among water and market policy changes in Algeria. Desalination 165:99-104. https://doi. org/10.1016/j.desa1.2004.06.011

Sahu P, Sikdar PK (2008) Hydrochemical framework of the aquifer in and around East Kolkata wetlands, West Bengal, India. Environ Geol 55:823-835

Selvakumar S, Chandrasekar N, Kumar G (2017) Hydrogeochemical characteristics and groundwater contamination in the rapid urban development areas of Coimbatore, India. Water Resour Ind 17:26-33. https://doi.org/10.1016/j.wri.2017.02.002

Sheikhy Narany T, Ramli MF, Aris AZ, Sulaiman WNA, Juahir H, Fakharian K (2014) Identification of the hydrogeochemical processes in groundwater using classic integrated geochemical methods and geostatistical techniques, in Amol-Babol Plain, Iran. Sci World J 2014:1-15. https://doi.org/10.1155/2014/419058

Singh KP, Malik A, Sinha S (2005) Water quality assessment and apportionment of pollution sources of Gomti river (India) using multivariate statistical techniques-a case study. Anal Chim Acta 1-2:355-374. https://doi.org/10.1016/j.aca.2005.02.006

Singh PK, Tiwari AK, Mahato MK (2013a) Qualitative assessment of surface water of West Bokaro Coalfield, Jharkhand by using water quality index method. Int J Chem Tech Res 5(5):2351-2356

Singh PK, Tiwari AK, Panigarhy BP, Mahato MK (2013b) Water quality indices used for water resources vulnerability assessment using GIS technique: a review. Int J Earth Sci Eng 6(6-1):1594-1600

Soltan ME (1999) Evaluation of groundwater quality in Dakhla Oasis (Egyptian Western Desert). Environ Monit Assess 57(2):157-168

Stambuk-Giljanovic N (1999) Comparison of Dalmatian water evaluation indices. Water Environ Res 75(5):388-405

Taheriyoun M, Karamouz M, Baghvand A (2010) Development of an entropy-based Fuzzy eutrophication index for reservoir water quality evaluation. Iran J Environ Health Sci Eng 7(1):1-14

Tiwari TN, Mishra M (1985) A preliminary assignment of water quality index to major Indian rivers. Indian J Environ Prot 5(4):276-279

Tiwari AK, Singh PK, Mahato MK (2014) GIS-based evaluation of water quality index of groundwater resources in West Bokaro Coal field, India. Curr World Environ 9(3):843-850. https://doi. org/10.12944/CWE.9.3.35
Tiwari AK, Singh AK, Singh MP (2015) Hydrogeochemical analysis and evaluation of surface water quality of Pratapgarh district, Uttar Pradesh, India. Appl Water Sci 7(4):1609-1623. https://doi. org/10.1007/s13201-015-0313-Z

Tiwari AK, Singh AK, Mahato MK (2017a) Assessment of groundwater quality of Pratapgarh district in India for suitability of drinking purpose using water quality index (WQI) and GIS technique. Sustain Water Resour Manag. https://doi.org/10.1007/s4089 9-017-0144-1

Tiwari AK, Ghione R, De Maio M, Lavy M (2017b) Evaluation of hydrogeochemical processes and groundwater quality for suitability of drinking and irrigation purposes: a case study in the Aosta Valley region. Arab J Geosci, Italy. https://doi.org/10.1007/s1251 7-017-3031-z

Touchan R, Anchukaitis KJ, Meko DM, Attalah S, Baisan C, Aloui A (2008) Long term context for recent drought in northwestern Africa. Geophys Res Lett 8(13):35. https://doi.org/10.1029/2008g 1034264

Tyagi S, Sharma B, Singh P, Dobhal R (2013) Water quality assessment in terms of water quality index. Am J Water Resour 1(3):34-38

UNEP, Water Research Commission (WRC) (2008) Freshwater under threat: Africa, vulnerability assessment of freshwater resources of environmental Change. UNEP and Water Research Commission, South Africa

Vasanthavigar M, Srinivasamoorthy K, Vijayaragavan K et al (2010) Application of water quality index for groundwater quality assessment: Thirumanimuttar sub-basin, Tamilnadu, India. Environ Monit Assess 171(1-4):595-609. https://doi.org/10.1007/s1066 1-009-1302-1

World Health Organization (WHO) (2011) Guidelines for drinking water quality, 4th edn. World Health Organization, Geneva

Publisher's Note Springer Nature remains neutral with regard to jurisdictional claims in published maps and institutional affiliations. 